\title{
Vertical Transmission of Coronavirus in Obstetrics: A Myth or Truth?
}

\author{
Salma Abdi Mahmoud1*, Ali M. Ussi², Chukwuma J. Okafor³ \\ ${ }^{1}$ Department of Obstetrics and Gynaecology, School of Health and Medical Sciences, The State University of Zanzibar, \\ Zanzibar, Tanzania \\ ${ }^{2}$ Department of Natural Sciences, The State University of Zanzibar, Zanzibar, Tanzania \\ ${ }^{3}$ Department of Pathology and Biochemistry, School of Health and Medical Sciences, The State University of Zanzibar, \\ Zanzibar, Tanzania \\ Email: *salma.mahmoud@suza.ac.tz
}

How to cite this paper: Mahmoud, S.A., Ussi, A.M. and Okafor, C.J. (2021) Vertical Transmission of Coronavirus in Obstetrics: A Myth or Truth? Open Journal of Obstetrics and Gynecology, 11, 309-314. https://doi.org/10.4236/ojog.2021.113031

Received: February 24, 2021

Accepted: March 21, 2021

Published: March 24, 2021

Copyright $\odot 2021$ by author(s) and Scientific Research Publishing Inc. This work is licensed under the Creative Commons Attribution International License (CC BY 4.0).

http://creativecommons.org/licenses/by/4.0/

\begin{abstract}
In obstetrics, the maternal immune system plays a critical role in the establishment and maintenance of a healthy pregnancy. The immune response of the placenta plays important role in determining a maternal vulnerability toward infectious diseases. The various adverse outcome, ranging from preterm birth, injury to the fetal brain cortex and fetal death are all documented in infected neonates. In obstetrics, viral infections can be either transmitted through the in-utero, intrapartum, and postpartum periods. Nevertheless, with the recent pandemic of coronavirus and some documented cases of a positively infected neonate, it is becoming more apparent that the mode of transmission of coronavirus during pregnancy needs to be better understood. This review focuses on revealing the possible modes of transmission of the coronavirus in obstetrics.
\end{abstract}

\section{Keywords}

Coronavirus, Obstetrics, In-Utero, Intrapartum, Postpartum

\section{Introduction}

Coronavirus is a virus that is structurally covered by a protein shell and inside it contains RNA that is specific to coronavirus. This virus is also known as SARSCOV-2. Genetically it is reported to be similar to the SARS variant that caused an outbreak in 2002, the only difference is the RNA inside them [1]. It is well known that, viruses need host cells to reproduce and keep dividing. The Coronavirus was reported to spread through cough, sneeze, or speech also, through 
prolonged unprotected contact with an infected person [2]. The vast majority of research on this virus is fast changing, the known facts and properties of the virus. Recent research reported that the virus can survive on a surface for up to 3 days and that social distancing can decrease the level of transmission [3]. The incubation period of this virus is reported to extend from 2 - 14 days [1], with the Virus starting to shed in 20 days or up to a maximum of 37 days. It affects both males and females with the median affected age range at 59 years. The most common classic symptoms are fever, cough, and shortness of breath. It can also present with emergency symptoms such as trouble breathing, persistent pain in the chest, confusion, or bluish lips and face [4].

To date, not much is known about coronavirus in obstetrics. However, it has been reported that coronavirus can be transmitted vertically in obstetrics [5]. Vertical transmission is a process by which an infected mother passes the virus to her fetus. There are still controversies about the possibility. Some of the literature showed that most of the infants that have been born to women who have coronavirus have tested negative [6]. However, other researchers have reported that the amniotic fluids, cord blood, and breast milk of infected women have been shown to contain coronaviruses [7].

From the literature, only a few studies showed that coronavirus can cause miscarriage [8]. Again, there are mixed data regarding the risk of birth defects in the setting of maternal fever. Consistently, during the coronavirus pandemic, there were no increases in birth defects or miscarriage to the mothers who were infected. In obstetrics, vertical transmission of coronavirus is reported to be through in utero, intrapartum or postpartum transmission [9] (Figure 1).

\section{In Utero Transmission of Coronavirus}

The in utero transmission can occur when the fetus swallows the amniotic fluids that have viral particles, or when the mother has severe coronavirus infection resulting in severe viremia. The infected blood enters the fetus via the placenta. It has been reported that the route of transmission is the placenta and amniotic membranes [10]. These membranes are reported to have a large surface area that is very close to the maternal decidual and can also serve as a conduit for transmission from the maternal side to the fetus [10] [11].

It has been reported that, the coronavirus binds to the human Angiotensinconverting enzyme 2 (ACE-2) receptor and facilitates its entry into the cells and promotes replications [12]. ACE-2 is shown to be expressed in both the maternal and fetal tissues. Current research results indicated that, ACE- 2 mRNA is expressed in fetal membranes and placenta tissues from early pregnancy to full term. Moreover, ACE-2 is highly expressed in Decidua and Chorion, then followed by Amnion [13]. The ACE-2 protein is also reported to be expressed in fetal tissues at twelve weeks gestation to twenty-four weeks and remains steady until delivery. Based on this, there are biological possibilities that coronavirus can be transmitted to the fetus through maternal-fetal tissues [12] [14]. 


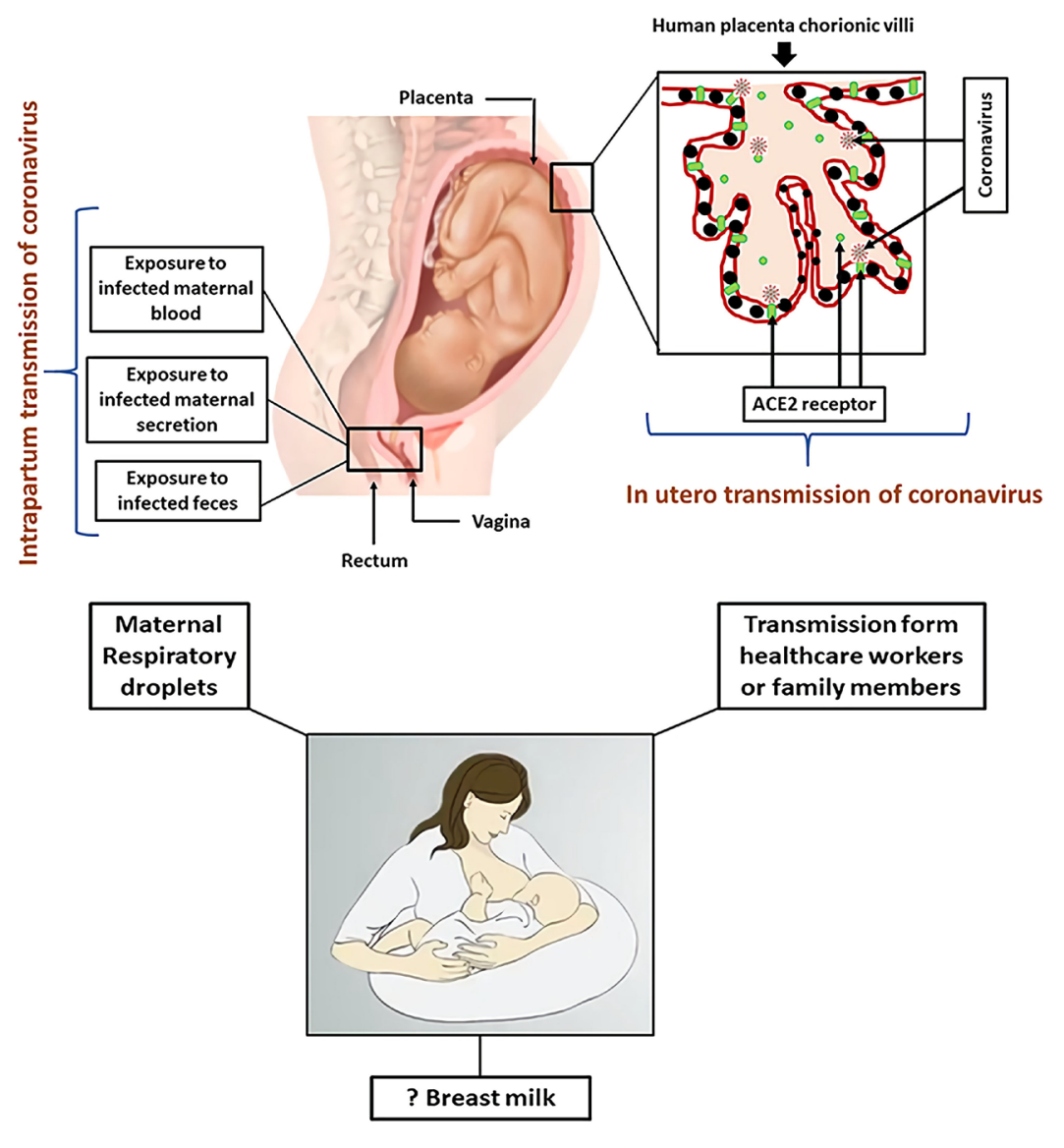

Postpartum transmission of Coronavirus

Figure 1. A schematic diagram showing the vertical transmission of coronavirus.

\section{Intrapartum Transmission of Coronavirus}

Intrapartum transmission of coronavirus occurs during the process of Child delivery [15]. When the newborn is exposed to the mother's blood or secretion it is known as early neonatal infection. Some literature e.g. [13] has reported that the virus transmission can also happen when the mother gets infected two weeks before delivery or 2 days after birth or when the baby has close contact with a caretaker who has the infection. Though other researchers e.g. Wu et al., reported that, the swab result may be negative in the baby on the $1^{\text {st }}$ day after birth, but it can later become positive when tested between the $2^{\text {nd }}$ and $4^{\text {th }}$ day due to the long incubation period of the coronavirus [16], although Egloff et al. reported that, coronavirus has not been detected in any vaginal fluid [10]. A study tested 10 postmenopausal women in the ICU with severe coronavirus infection and did not find any coronavirus in vaginal fluids [15]. Again, a total of 6 pregnant women who were coronavirus positive did not show any coronavirus in their vaginal fluids [17]. This number is very limited, and more research needs to be carried out to ascertain the presence or otherwise of coronavirus in vaginal fluids. However, the live virus was reported to be found from 4 stool samples from the infected women [18]. Coronavirus has been detected in blood samples 
of a few infected women. A study done by Wang et al. reported that, out of 307 positive women, only three had a positive blood test for the Coronavirus [19]. Generally, the presented statistics do not conclusively reveal the most possible intrapartum transmission of coronavirus. Therefore, more research needs to be done regarding the intrapartum transmission of the coronavirus to the fetus.

\section{Postpartum Transmission of Coronavirus}

There is always a risk of immediate post-natal transmission in the delivery room, most likely due to transmission from respiratory droplets as a result of close contact nursing. Currently, there are no transmission cases have been reported for Postpartum transmission of coronavirus. Postpartum transmission of coronavirus risk is not associated with breastmilk. However, the testing of breastmilk samples for the COVID-19 from 17 infected women who were breastfeeding mothers, revealed to have no detection of coronaviruses [20].

\section{Serologic Evidence for Vertical Transmission}

Serologic testing for evidence of humoral immune response to the virus still needs to be widely validated in terms of test performance and cross-reactivity. There are two published reports about serologic vertical transmission. The first case was an infant delivered by caesarian section at 37 weeks, whose nasopharyngeal swabs were negative $2 \mathrm{hrs}$ after delivery, but was positive for IgM and IgG [21]. The second case report was of 6 infants delivered by caesarian section who all had positive IgM and IgG antibodies [22]. All were asymptomatic and nasopharyngeal swabs PCR positive. However, IgM and IgG assays are prone to false positives, meaning that serologic assays are not yet well validated for coronavirus [23]. The results revealed that all RT-PCR in neonatal specimens were negative. The results imply that serologic testing alone should not be considered as proof in utero transmission.

\section{Summary}

To date, reported evidences regarding the coronavirus transmission in utero, intrapartum and postpartum period are not conclusively enough to reveal the case. Furthermore, serologic evidence for vertical transmission of coronavirus is still needs to be validated. It is important to be vigilant to better understand the mode of transmission of coronavirus in obstetrics. Likewise, standard intervention and proper contact precaution need to be implemented aggressively in a team-based care model.

\section{Conflicts of Interest}

The authors declare no conflicts of interest regarding the publication of this paper.

\section{References}

[1] Esakandari, H., Nabi-Afjadi, M., Fakkari-Afjadi, J., Farahmandian, N., Miresmaeili, 
S.-M. and Bahreini, E. (2020) A Comprehensive Review of COVID-19 Characteristics. Biological Procedures Online, 22, Article No. 19. https://doi.org/10.1186/s12575-020-00128-2

[2] Rasmussen, S.A., Smulian, J.C., Lednicky, J.A., Wen, T.S. and Jamieson, D.J. (2020) Coronavirus Disease 2019 (COVID-19) and Pregnancy: What Obstetricians Need to Know. American Journal of Obstetrics and Gynecology, 222, 415-426. https://doi.org/10.1016/j.ajog.2020.02.017

[3] Singhal, T. (2020) A Review of Coronavirus Disease-2019 (COVID-19). Indian Journal of Pediatrics, 87, 281-286. https://doi.org/10.1007/s12098-020-03263-6

[4] Ye, Z.-W. and Jin, D.-Y. (2020) Diagnosis, Treatment, Control and Prevention of SARS-CoV-2 and Coronavirus Disease 2019: Back to the Future. Chinese Journal of Biotechnology, 36, 571-592.

[5] Alzamora, M.C., Paredes, T., Caceres, D., Webb, C.M., Valdez, L.M. and La Rosa, M. (2020) Severe COVID-19 during Pregnancy and Possible Vertical Transmission. American Journal of Perinatology, 37, 861-865.

https://doi.org/10.1055/s-0040-1710050

[6] Diriba, K., Awulachew, E. and Getu, E. (2020) The Effect of Coronavirus Infection (SARS-CoV-2, MERS-CoV, and SARS-CoV) during Pregnancy and the Possibility of Vertical Maternal-Fetal Transmission: A Systematic Review and Meta-Analysis. European Journal of Medical Research, 25, 39. https://doi.org/10.1186/s40001-020-00439-w

[7] Yan, J., Guo, J., Fan, C., Juan, J., Yu, X., Li, J., Feng, L., Li, C., Chen, H., Qiao, Y., Lei, D., Wang, C., Xiong, G., et al. (2020) Coronavirus Disease 2019 in Pregnant Women: A Report Based on 116 Cases. The American Journal of Obstetrics and Gynecology, 223, 111.e1-111.e14. https://doi.org/10.1016/j.ajog.2020.04.014

[8] Cosma, S., Carosso, A.R., Cusato, J., Borella, F., Carosso, M., Bovetti, M., Filippini, C., D’Avolio, A., Ghisetti, V., Di Perri, G. and Benedetto, C. (2020) Coronavirus Disease 2019 and First-Trimester Spontaneous Abortion: A Case-Control Study of 225 Pregnant Patients. American Journal of Obstetrics and Gynecology. https://doi.org/10.1016/j.ajog.2020.10.005

[9] Chen, H., Guo, J., Wang, C., Luo, F., Yu, X., Zhang, W., Li, J., Zhao, D., Xu, D., Gong, Q., Liao, J., Yang, H., Hou, W., et al. (2020) Clinical Characteristics and Intrauterine Vertical Transmission Potential of COVID-19 Infection in Nine Pregnant Women: A Retrospective Review of Medical Records. The Lancet (London, England), 395, 809-815. https://doi.org/10.1016/S0140-6736(20)30360-3

[10] Egloff, C., Picone, O., Vauloup-Fellous, C. and Roques, P. (2020) Mother to Child SARS-CoV-2 Transmission: Fact or Fantasy. Virologie (Montrouge, France), 24, 142 146. https://doi.org/10.1684/vir.2020.0838

[11] Fathi, M., Vakili, K., Deravi, N., Yaghoobpoor, S., Ahsan, E., Mokhtari, M., Moshfeghi, M. and Vaezjalali, M. (2020) Coronavirus Diseases and Pregnancy: COVID-19, SARS, and MERS. Przeglad Epidemiologiczny, 74, 276-289. https://doi.org/10.32394/pe.74.21

[12] Phoswa, W.N. and Khaliq, O.P. (2020) Since January 2020 Elsevier Has Created a COVID-19 Resource Centre with Free Information in English and Mandarin on the Novel Coronavirus COVID-19. The COVID-19 Resource Centre Is Hosted on Elsevier Connect, the Company's Public News and Information.

[13] Zheng, T., Guo, J., He, W., Wang, H., Yu, H. and Ye, H. (2020) Coronavirus Disease 2019 (COVID-19) in Pregnancy: 2 Case Reports on Maternal and Neonatal Outcomes in Yichang City, Hubei Province, China. Medicine (Baltimore), 99, e21334. 
https://doi.org/10.1097/MD.0000000000021334

[14] Elrashdy, F., Redwan, E.M. and Uversky, V.N. (2020) Why COVID-19 Transmission Is More Efficient and Aggressive than Viral Transmission in Previous Coronavirus Epidemics? Biomolecules, 10, 1312. https://doi.org/10.3390/biom10091312

[15] Mullins, E., Evans, D., Viner, R.M., O’Brien, P. and Morris, E. (2020) Coronavirus in Pregnancy and Delivery: Rapid Review. Ultrasound in Obstetrics \& Gynecology, 55, 586-592. https://doi.org/10.1002/uog.22014

[16] Wu, Y.-T., Liu, J., Xu, J.-J., Chen, Y.-F., Yang, W., Chen, Y., Li, C., Wang, Y., Liu, H., Zhang, C., Jiang, L., Qian, Z.-X., Kawai, A., et al. (2020) Coronavirus Disease 2019 (COVID-19) in Pregnancy: 2 Case Reports on Maternal and Neonatal Outcomes in Yichang City, Hubei Province, China. PLOS Medicine, 17, e1003195. https://doi.org/10.1371/journal.pmed.1003195

[17] Auriti, C., Rose, D.U., Tzialla, C., Caforio, L., Ciccia, M., Manzoni, P. and Stronati, M. (2020) Vertical Transmission of SARS-CoV-2 (COVID-19): Are Hypotheses More than Evidences? American Journal of Perinatology, 37, S31. https://doi.org/10.1055/s-0040-1714346

[18] Xiao, F., et al. (2020) Infectious SARS-CoV-2 in Feces of Patient with Severe COVID-19. Emerging Infectious Diseases, 26, 1920-1922.

https://doi.org/10.3201/eid2608.200681

[19] Dong, L., et al. (2020) Possible Vertical Transmission of SARS-CoV-2 from an Infected Mother to Her Newborn. JAMA, 323, 1846-1848.

[20] Centeno-Tablante, E., et al. (2020) Transmission of SARS-CoV-2 through Breast Milk and Breastfeeding: A Living Systematic Review. Annals of the New York Academy of Sciences, 1484, 32-54.

[21] Zeng, H., Xu, C., Fan, J., Tang, Y., Deng, Q., Zhang, W. and Long, X. (2020) Antibodies in Infants Born to Mothers with COVID-19 Pneumonia. JAMA, 323, 18481849. https://doi.org/10.1001/jama.2020.4861

[22] Di Toro, F., et al. (2021) Impact of COVID-19 on Maternal and Neonatal Outcomes: A Systematic Review and Meta-Analysis. Clinical Microbiology and Infection, 27, 36-46.

[23] Tahamtan, A. and Ardebili, A. (2020) Real-Time RT-PCR in COVID-19 Detection: Issues Affecting the Results. Expert Review of Molecular Diagnostics, 20, 453-454. https://doi.org/10.1080/14737159.2020.1757437 